\title{
Effect of Cytokinins on Micropropagation of Anoectochilus elatus Lindl. from shoot tip explants - An Endangered Medicinal Orchid.
}

\author{
*Dr. H. David Raja ${ }^{1}$ \\ Assistant Professor Gnanarethinam Centre for In vitro Conservation (GCIC) Department of Botany \\ St. Joseph's College, Tiruchirappalli - 600002, Tamil Nadu, India.
}

\begin{abstract}
Micropropagation of Orchids species has always been a challenging task. An efficient protocol for rapid Micropropagation of Anoectochilus elatus Lindley has been developed from shoot tip explants. Explants were cultured on Murashige and Skoog (MS) medium supplemented with BAP (6-Benzylamino purine 1 - 5 $\mathrm{mg} / \mathrm{l}$ ), TDZ (Thidiazuron $0.5-3.0 \mathrm{mg} / \mathrm{l}$ ) and KIN (Kinetine $1-5 \mathrm{mg} / \mathrm{l}$ with $5 \%$ of Coconut Water $(\mathrm{CW}) .2 .5 \mathrm{mg} / \mathrm{l}$ $T D Z+5 \% C W$ were proved to be best for high frequency multiple shoot induction from shoot-tip explants. The response was maximum $(90 \%)$ at $2.5 \mathrm{mg} / \mathrm{l} \mathrm{TDZ}+5 \% \mathrm{CW}$ and the maximum number of multiple shoots produced was 7 per culture with $6.2 \mathrm{~cm}$ of mean shoot length. The well elongated healthy shoots were transferred for ex vitro rooting supplemented with IBA (Indole-3-Butyric Acid) and IAA (Indole Acetic Acid) in different concentration. Maximum numbers of ex vitro roots were achieved in $7.0 \mathrm{mg} / \mathrm{l}$ of IBA concentration. The rooted plantlets were hardened and reintroduced in natural habitats of Kolli Hills. The maximum survival percentage (88\%) was observed in Kulivalavu regions (KU-3 Site) of Kolli Hills. All the regenerated plants were normal with respect to morphology and growth characteristics.
\end{abstract}

Keywords: Anoectochilus elatus, Ex vitro rooting, Micropropagation, Multiple shoots, Shoot tip.

\section{Introduction}

India is a major centre of origin and rich diversity of various types of plant species due to its diverse climatic zones. In India, among the various plant groups, Orchids are the queen of plant kingdom because of their scintillating colourful attractive flowers and medicinal uses. Anoectochilus elatus Lindley is an important threatened medicinal orchid belonging to family orchidaceae commonly known as "Jewel orchids" because of their attractive leaf venation arrangements (Ket et al., 2004). The genus Anoectochilus consists of approximately 50 species belonging to a group of terrestrial orchids. Anoectochilus elatus Lindley is an endangered orchid endemic to Tamil Nadu and Kerala (Kumar et al., 2001). There is very high potential demand for this species both for medicinal value and for its ornamental value. Anoectochilus elatus species have been used in Traditional Chinese medicine and used for hypertension, respiratory and liver diseases, chest and abdominal pains (Zheng et al., 1996).

In nature, the reproducing capacity of Anoectochilus elatus is very less due to several limiting factors like poor endosperm formation during the fruit set, lack of symbiotic relationship to orchid fungi, low range of rainfall etc. During the several field visits of Kolli Hills of Eastern Ghats, We observed that, distribution of Anoectochilus elatus populations were highly restricted due to the destruction of their natural habitats and the conversion of forest into agricultural lands. The mass propagation of orchids through plant tissue culture is a more reliable tool for the ex situ conservation of the declining orchids like Anoectochilus elatus. The ultimate aim of micropropagation work is to increase the Anoectochilus elatus populations in sustainable manner in the study area with reintroduction of tissue cultured raised plantlets.

\section{Materials And Methods}

According to the previous review of literature information and Tamilnadu Carnatic flora book references were used to find out the plant availability locality in Kolli Hills. Anoectochilus elatus plants mostly grow in deep evergreen forest shade on moist forest floors with rich layer of black loamy soils. The frequent field visits of Kolli Hills, We observed that, distribution of Anoectochilus elatus Lindl was found in Kulivalavu and Sholakadu regions of Kolli Hills. Due to rarity of the Anoectochilus elatus, few plantlets were collected and established in Botany Department garden for further use. Hence, we arranged some special setup for orchids growing environment in the Botany Department with help of Shade hut, Coconut Husk, using Moss pouches, Nutrient solution (Knops solution) etc.

Sterilization of explants is skilful scientific art because the percentage of explants response fixed based on the sterilization process. The present study, various steps were followed for explants sterilization based on the condition of explants. Anoectochilus elatus shoot tip segments were excised from healthy disease free 
plantlets. In explants sterilization process excised shoot tips were washed with running tap water for 10 minutes and with $2 \%(\mathrm{~W} / \mathrm{V})$ Teepol (Soap water) for 5 minutes. Then shoot tips were treated with $5 \%$ of Bavistin (Fungicide) for 5 minutes and washed 5-6 times with distilled water. Further sterilization treatments were done under a laminar-flow chamber. After rinsing with sterile double distilled water they were surface sterilized in $0.1 \%$ (W/V) $\mathrm{HgCl}_{2}$ for $10 \mathrm{~min}$ and again rinsed thoroughly with sterile double distilled water. The shoot tips were inoculated on MS basal medium (Murashige and Skoog, 1962) containing $3 \%$ (W/V) sucrose, and solidified with $0.8 \%$ (W/V) agar. The $\mathrm{pH}$ of the medium was adjusted to 5.7 before gelling with agar. All the cultures were inoculated in a growth room with a $16 \mathrm{~h}$ photoperiod (cool, white fluorescent light $-30 \mu \mathrm{mol} \mathrm{m} / \mathrm{s}$ ) and the temperature maintained at $25 \pm 2^{\circ} \mathrm{C}$, with $50-80 \%$ relative humidity.

\section{Results And Discussion}

Anoectochilus elatus is one of the important rare medicinal orchids of Kolli Hills and its population is becoming restricted due to high medicinal properties and several aspects of anthropogenic activities. Incidentally Anoectochilus elatus is placed under near threatened category of IUCN. Tissue culture is a more reliable technique to conserve the threaten category of plant species. Micropropagation was carried out by shoot tip explants. Micropropagation through multiple shoot induction is a rapid and much reliable plant regeneration method of producing mass quantity of plantlets from shoot tip explants. Though, shoot tip explants are normally used for such purpose in the present study.

Induction of multiple shoots was carried out with aid of various concentration of BAP (1- $5 \mathrm{mg} / \mathrm{l})$, TDZ (0.5- $3.0 \mathrm{mg} / \mathrm{l})$ and $\mathrm{KIN}(1-5 \mathrm{mg} / \mathrm{l})$ with Coconut Water. Microshoots were not produced in Cytokinin free medium (Basal medium). Shoot tip segments began to response after 25 days on MS medium supplemented with various concentration of Cytokinins. The observations on the effect of BAP, KIN and TDZ on multiple shoot induction from shoot tip explants are shown in Table-1. The response was maximum (90\%) at $2.5 \mathrm{mg} / 1$ $\mathrm{TDZ}+5 \% \mathrm{CW}$ and the maximum number of multiple shoots produced was 7 per culture with $6.2 \mathrm{~cm}$ of mean shoot length after the 60 days incubation (Table -1 , Fig - b, c, d \& e). In BAP, maximum number of shoots (43.3\% Response and 2 Shoots/Explants with $3.0 \mathrm{~cm}$ shoot length) was produced in $3 \mathrm{mg} / \mathrm{l} \mathrm{BAP}+5 \% \mathrm{CW}$ concentration. The percentage of the response and the number of shoots/explants and mean shoot length produced are expressed in Table -1. The maximum number of shoots was 7 per culture with $6.2 \mathrm{~cm}$ of mean shoot length observed at $2.5 \mathrm{mg} / \mathrm{TDZ}+5 \% \mathrm{CW}$. Similar results were also obtained from Habenaria bractescens Lindl fortified with $2.5 \mathrm{mg} / \mathrm{l}$ of TDZ reported by Medina et al., 2009. Addition of $50 \mathrm{mg} / \mathrm{l}$ of Charcoal or $1 \mathrm{mg} / \mathrm{l}$ of Ascorbic acid to the culture medium facilitated shoot growth and reduced the browning of tissues. After the sufficient elongation of shoots, the well-elongated shoots were harvested and treated with root inducing hormones for root formation.

TABLE - 1: Effect of various concentrations of Cytokinins and Coconut water on Shoot regeneration of Anoectochilus elatus from Shoot tip Explants after two months of Culture

\begin{tabular}{|c|c|c|c|c|c|}
\hline $\begin{array}{c}\text { Hormone Concentration } \\
\mathrm{mg} / \mathrm{l}\end{array}$ & $\begin{array}{c}\text { No. of } \\
\text { Explants } \\
\text { Cultured } \\
\end{array}$ & $\begin{array}{c}\text { No. of } \\
\text { Explants } \\
\text { Responded }\end{array}$ & $\begin{array}{l}\text { Percentage of } \\
\text { Response }\end{array}$ & $\begin{array}{c}\text { No. Shoots / } \\
\text { Explant } \\
\text { Mean } \pm \text { SE }\end{array}$ & $\begin{array}{l}\text { Mean Shoot } \\
\text { Length }(\mathrm{cm})\end{array}$ \\
\hline \multicolumn{6}{|l|}{$\mathbf{B A P}+\mathbf{C W}$} \\
\hline $1+5 \% \mathrm{CW}$ & 30 & 3 & 10.0 & $1.42 \pm 0.46$ & 1.8 \\
\hline $2+5 \% \mathrm{CW}$ & 30 & 8 & 26.6 & $1.68 \pm 0.33$ & 2.0 \\
\hline $3+5 \% \mathrm{CW}$ & 30 & 13 & 43.3 & $2.00 \pm 0.45$ & 3.0 \\
\hline $4+5 \% \mathrm{CW}$ & 30 & 12 & 40.0 & $1.72 \pm 0.60$ & 3.0 \\
\hline $5+5 \% \mathrm{CW}$ & 30 & 10 & 33.3 & $1.72 \pm 0.60$ & 2.6 \\
\hline \multicolumn{6}{|l|}{ TDZ + CW } \\
\hline $0.5+5 \% \mathrm{CW}$ & 30 & 9 & 30.0 & $1.52 \pm 0.46$ & 3.2 \\
\hline $1.0+5 \% \mathrm{CW}$ & 30 & 12 & 40.0 & $2.38 \pm 0.13$ & 3.6 \\
\hline $1.5+5 \% \mathrm{CW}$ & 30 & 16 & 53.3 & $2.20 \pm 0.14$ & 4.3 \\
\hline $2.0+5 \% \mathrm{CW}$ & 30 & 21 & 70.0 & $3.22 \pm 0.18$ & 4.0 \\
\hline $2.5+5 \% \mathrm{CW}$ & 30 & 27 & 90.0 & $7.00 \pm 0.32$ & 6.2 \\
\hline $3.0+5 \% \mathrm{CW}$ & 30 & 22 & 73.3 & $3.00 \pm 0.12$ & 4.8 \\
\hline \multicolumn{6}{|l|}{$\mathbf{K I N}+\mathbf{C W}$} \\
\hline $1+5 \% \mathrm{CW}$ & 30 & 2 & 6.6 & $1.14 \pm 0.14$ & 1.5 \\
\hline $2+5 \% \mathrm{CW}$ & 30 & 3 & 10 & $1.14 \pm 0.14$ & 1.7 \\
\hline $3+5 \% \mathrm{CW}$ & 30 & 14 & 46.6 & $1.76 \pm 0.45$ & 2.8 \\
\hline $4+5 \% \mathrm{CW}$ & 30 & 15 & 50.0 & $1.38 \pm 0.22$ & 2.6 \\
\hline $5+5 \% \mathrm{CW}$ & 30 & 11 & 36.6 & $1.22 \pm 0.50$ & 2.0 \\
\hline
\end{tabular}

\section{Ex vitro Root Induction of Micropropagated Shoots}

After sufficient elongation of in vitro propagated shoots i.e. shoots exceeding $5 \mathrm{~cm}$ in length were excised and treated with different concentrations of IBA and IAA for 24 hours to induce the ex vitro rooting. 
After the 24 hours treatment of IBA and IAA well elongated micropropagated shoots were placed in the small poly bags or plastic cups containing mixture of Black loamy soil, dried Moss powder, Vermiculate and Coconut husk in the ratio of 1:1:1:1 combination to facilitate the root formation. The potted shoots were fortified with quarter strength of M.S. liquid solution for a week. The root initiation was visually observed only after 21 days and the full plantlet with sufficient root growth could be produced in after 36 days. For ex vitro root induction IBA and IAA were used in the range of $5.0-10.0 \mathrm{mg} / \mathrm{l}$. The number of shoots in which successful root induction was carried out in shoots obtained from shoot tip explants was shown in Table - 2. IBA at $7.0 \mathrm{mg} / \mathrm{l}$ was found to be ideal for ex vitro root induction. The percentage of response of shoots for rooting ranged from $20-86.6$ in various concentrations of IBA and IAA. The maximum percentage of response $(86.6 \%)$ and formation of healthy roots were achieved in IBA at $7.0 \mathrm{mg} / \mathrm{l}$ found to be effective for ex vitro rooting in the well elongated micropropagated shoots.

Roots are mostly induced in the presence of suitable Auxins (IBA or IAA) in the medium. Similar results were also obtained from Merremia quinquefolia fortified with $2.0 \mathrm{mg} / \mathrm{l}$ of IBA reported by Mafatlal et al., 2015. In vitro regenerated shoots of Gentiana kurroo Royle were rooted in six weeks when transferred to half strength MS medium supplemented with $5.0 \mathrm{mg} / \mathrm{l}$ Indole butyric acid (Shiwani Kaushal et al., 2014). In vitro shoots of Ocimum sanctum Linn. were rooted on $4.5 \mathrm{mg} / 1$ of Indole Butyric Acid (IBA) supplemented medium (Tulika Mishra., 2015). A comparison of results in IBA and IAA reveals that, IBA is more effective than IAA both in terms of performance and hormone requirement as well.

TABLE - 2: Effect of IBA and IAA on Ex vitro Root induction of Anoectochilus elatus from Shoot tip

\begin{tabular}{|c|c|c|c|c|}
\hline $\begin{array}{c}\text { Hormone Concentration } \\
\text { mg/l }\end{array}$ & $\begin{array}{l}\text { No. of Explants } \\
\text { Cultured }\end{array}$ & $\begin{array}{l}\text { No. of Explants } \\
\text { Responded }\end{array}$ & $\begin{array}{c}\text { Percentage of } E x \\
\text { vitro } \\
\text { Rooting }\end{array}$ & $\begin{array}{c}\text { Mean Root Length } \\
(\mathbf{c m})\end{array}$ \\
\hline \multicolumn{5}{|l|}{ IBA } \\
\hline 5.0 & 30 & 11 & 36.6 & 1.6 \\
\hline 6.0 & 30 & 18 & 60.0 & 3.2 \\
\hline 7.0 & 30 & 26 & 86.6 & 4.4 \\
\hline 8.0 & 30 & 20 & 66.6 & 3.7 \\
\hline 9.0 & 30 & 13 & 43.3 & 2.6 \\
\hline 10.0 & 30 & 10 & 33.3 & 1.3 \\
\hline \multicolumn{5}{|l|}{ IAA } \\
\hline 5.0 & 30 & 6 & 20.0 & 0.6 \\
\hline 6.0 & 30 & 12 & 40.0 & 0.9 \\
\hline 7.0 & 30 & 14 & 46.6 & 1.2 \\
\hline 8.0 & 30 & 15 & 50.0 & 2.5 \\
\hline 9.0 & 30 & 10 & 33.3 & 1.5 \\
\hline 10.0 & 30 & 8 & 26.6 & 1.0 \\
\hline
\end{tabular}

\section{Hardening}

After the sufficient root and shoot development, the healthy plantlets were reintroduced in the natural habitats of Kolli Hills of Eastern Ghats. The various final survival rate of hardening percentage was observed by frequent field visits. Maximum survival of hardening percentage (88\%) was observed in Kulivalavu regions (KU-3 Site) of Kolli Hill after 60 days.
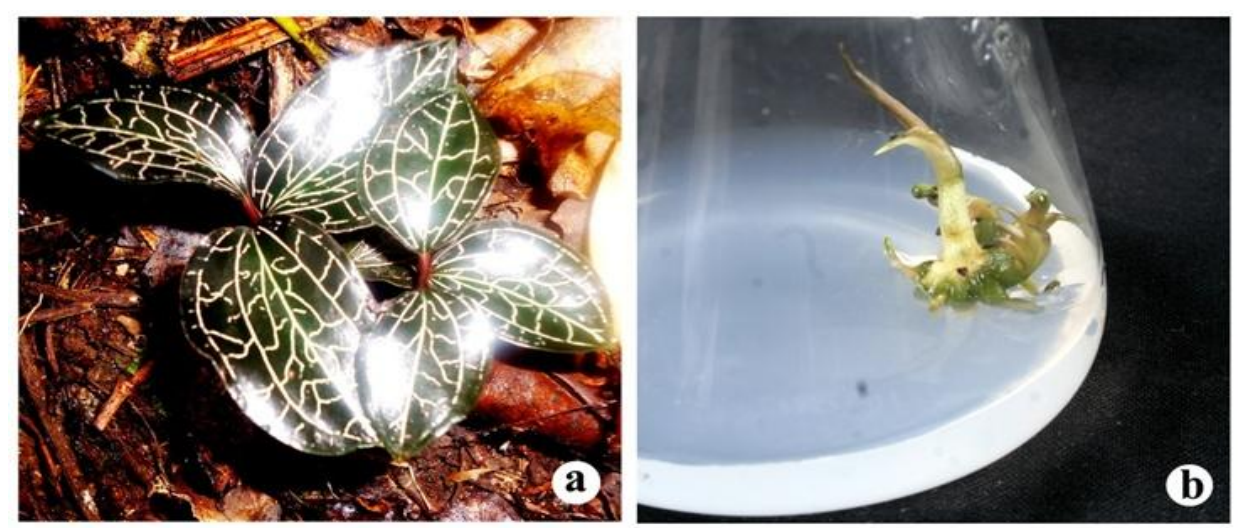

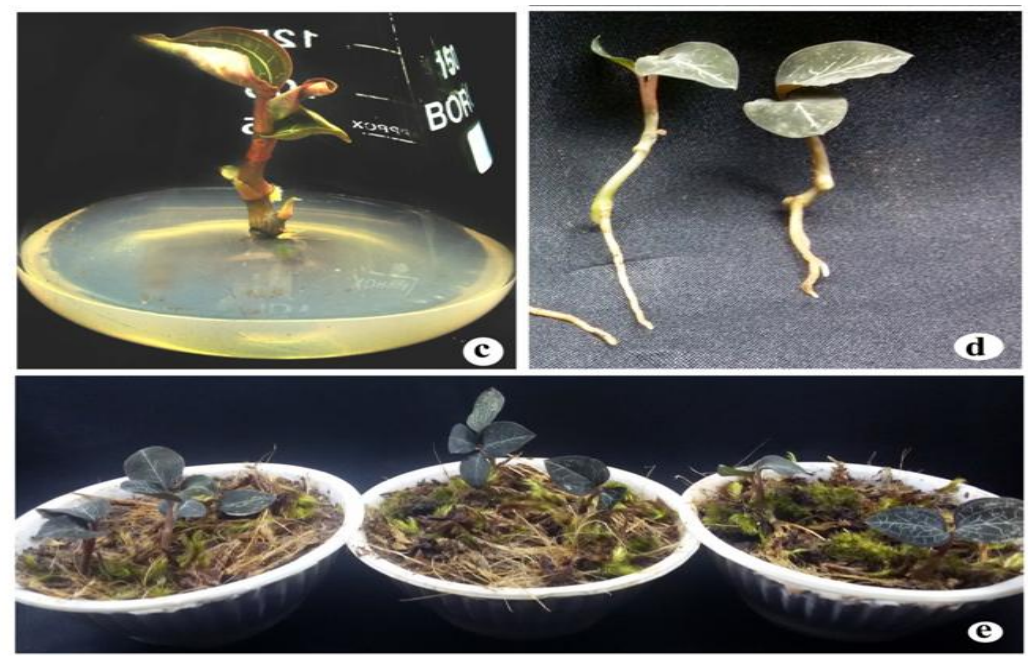

Fig. 1: Various stages of micropropagation from shoot tip explants of Anoectochilus elatus Lindl. (a) Habit; (b) Microshoots proliferation from shoot tip explant; (c) Shoots elongation with leafs; (d) Rooted plantlets; (e) Hardened plantlets

\section{Conclusion}

The most reliable and rapid method of micropropagation has been produced from shoot tip explants of Anoectochilus elatus using various types and concentration Cytokinins. However, the responses in higher and lower dosage were decreased in multiple shoot formation. A comparison of efficiency of Cytokinins indicates that $\mathrm{TDZ}+5 \% \mathrm{CW}$ are certainly superior to $\mathrm{BAP}+5 \% \mathrm{CW}$ because the response of explants was $90 \%$. The number of average microshoots was 7 at $2.5 \mathrm{mg} / \mathrm{TDZ}+5 \% \mathrm{CW}$. Hence, TDZ is ideal in the microropagation of Anoectochilus elatus from shoot tip explants. For ex vitro root induction IBA and IAA were used in the concentration of $5.0-10.0 \mathrm{mg} / \mathrm{l}$. The maximum ex vitro root induction was achieved in $7.0 \mathrm{mg} / \mathrm{lBA}$. Among the two rooting hormones $7.0 \mathrm{mg} / \mathrm{IBA}$ were produced highest $(86.6 \%)$ percentage of root induction. The highest percentage of the survival was $88 \%$ were noted in Kulivalavu regions (KU-3 Site) of Kolli Hills. This study's main objective was to develop an efficient method for mass propagation of Anoectochilus elatus in short span of time. The present micropropagation protocol is very useful to reproduce large number of Anoectochilus elatus plantlets from shoot tip explants.

\section{Acknowledgements}

I acknowledge the financial assistance from University Grand Commission (UGC - SERO), Government of India, New Delhi in the form of Minor Research Project.

\section{References}

[1] NV. Ket, EJ .Hahn, SY.Park, D. Chaharabarty, KY. Paek (2004). Micropropagation of an endangered orchid Anoectochilus formosanus. Biol. Plant. 48(3): 339-344.

[2] SC . Kumar, BV. Shetty, SSR. Bennet, T. Ananda Rao, S. Sanjay Molur (2001). Endemic Orchids of the Western Ghats. Conservation Assessment and Management Plan (CAMP) Workshop Report.

[3] C. Zheng, YZ. Huang, LF. Ji (1996). Pharmacognostical studies on Jin Xian Lian. Zhongcaoyao, 27: 169-172.

[4] T. Murashige and A. Skoog (1962). A revised medium for rapid growth and bioassays with Tobacco tissue culture. Physiol. Plant, 15 (1962) 473-497.

[5] [R D. Medina, EA. Flachsland, AM. Gonzalez, G. Terada, MM. Faloci and LA. Mroginski (2009). In vitro tuberization and plant regeneration from multi-nodal segment culture of Habenaria bractescens Lindl., an Argentinean wetland orchid. Plant Cell Tiss Organ Cult (2009) 97:91-101.

[6] M. Mafatlal, M. Kher, Nataraj, D. Hettal, Parmar and H. Buchad (2015). Micropropagation of Merremia quinquefolia (1.) hallier f. from nodal explants. Journal of Horticultural Research, 23(1): 13-16.

[7] T. Mishra (2015). Protocol establishment for multiplication and regeneration of 'Holy Basil' (Ocimum sanctum Linn). Journal of medicinal plants studies 3(4): 16-19.

[8] S. Kaushal, A. Sidana and K. Dev (2014). In vitro plant production through apical meristem culture of Gentiana kurroo Royle. Journal of medicinal plants studies 3(1): 04-09.

IOSR Journal of Biotechnology and Biochemistry (IOSR-JBB) is UGC approved Journal with Sl. No. 4033, Journal no. 44202.

Dr. H. David Raja. "Effect of Cytokinins on Micropropagation of Anoectochilus elatus Lindl. from shoot tip explants - An Endangered Medicinal Orchid." IOSR Journal of Biotechnology and Biochemistry (IOSR-JBB) 3.3 (2017): 73-76. 